\title{
The Electronic Monitoring of Offenders in Context: From Policy to Political Logics
}

\author{
Emma Laurie $^{1} \cdot$ Giuseppe Maglione $^{1}$ (D)
}

Published online: 31 October 2019

(c) The Author(s) 2019

\begin{abstract}
The electronic monitoring (EM) of offenders is a subject that has been researched widely within criminology. Theoretical engagement with this instrument has been limited, however. The criminological literature, in fact, has focused primarily on empirical assessments of EM's financial and technical aspects, as well as on the legal implications of EM and its impact on reoffending. Against this backdrop, this article provides a critical examination of EM, focussing on how policy construes this penal measure, using Scotland as an example. In addition, drawing on Foucault's notion of governmentality, this article explores and problematizes the political logics (neoliberal, nationalist and techno-communitarian) which inform EM policy in the context of Scotland. The final section shifts the focus from exposing the political milieu within which EM policy emerges to contesting its possible effects, thereby extending the political critique of EM policy. The overarching aim is to contribute toward a nuanced political assessment of EM, while presenting directions for future engagement with this subject.
\end{abstract}

\section{Introduction}

Most of the criminological literature on the electronic monitoring (EM) of offenders centers on its financial and technical implications, its historical roots and its impact on reoffending, as well as on its place within criminal justice systems across the world (Bartels and Martinovic 2017). There remains, however, a lack of critical criminological scrutiny of EM policy and practice. In fact, when policy is considered, it is usually as an introductory section of empirical analyses (Graham and McIvor 2015, 2017; Hucklesby et al. 2016; McIvor and Graham 2016), and it rarely includes fine-grained examinations of the politics informing such policy frameworks (Jones 2014; Nellis 2006; Payne and Gainey 2000). This article rests on the broader premise that penal policy is a political device in that it seeks to "act upon the possibilities of action of other people" (Foucault 1982: 341) and that neglecting this political dimension equates with committing the "original sin of criminological positivism" (Matza 1969: 143). From this viewpoint, this article offers a theoretically informed

Giuseppe Maglione

G.Maglione@napier.ac.uk

1 School of Applied Sciences, Edinburgh Napier University, Sighthill Campus, Edinburgh EH114BN, UK 
analysis of EM policy, using Scotland as a case study, in order to illustrate the political logics that underpin such policy in specific contexts (cf. Maglione 2018a).

After an overview of the context and research literature on EM and a methodological introduction, this article unpacks EM policy, looking at how such policy construes distinctive "problems," "subjects," "objects" and "places" and uncovering the tacit assumptions behind such constructions (Bacchi 2009, 2012). The second part of the article interprets such representations by situating them in their political milieu, drawing on Foucault's (2007, 2008) notion of governmentality and subsequent extensions thereof (e.g., Miller and Rose 1990; O’Malley 1999; Rose et al. 2006). As a result, EM emerges as a multilayered policy instrument geared toward governing segments of populations, according to specific political logics. The final section shifts the focus from examining the political dimension of EM policy to a critique of its possible effects.

The overarching aim is to contribute toward a "thick" understanding of EM, challenging the interpretation of this measure as a "mere" neoliberal penal innovation (Feeley and Simon 1992; Garland 2001; Nellis 2014a; Nellis and Bungerfeldt 2013; Paterson 2008, 2015). In pursuing this objective, this article enriches the debate around the present and the future of EM, while providing material for contesting its political effects. In addition, it imparts a cursory and original snapshot of (Scottish) politics as seen through the lens of penal policy.

\section{Policy Context and Prior Research on Electronic Monitoring}

EM originated in the US in the late 1980s, spreading quickly across Europe in the 1990s as a device for monitoring people on probation and as a possible alternative to bail and prison sentences (Nellis 2006). Today, in most English-speaking countries, it appears to be a "regularly applied penal measure" (Bartels and Martinovic 2017: 80). EM has existed in Scotland since the late 1990s as a stand-alone measure for both adults and young offenders-either as a community penalty or with prisoners on early release (Graham and McIvor 2017: 65). Currently, EM is discussed mainly in the context of "robust community sentences"- as an instrument to tackle the Scottish prison population, which is relatively high compared to the rest of Europe ${ }^{1}$ (Graham and McIvor 2017: 67). In light of this, the Scottish National Party ${ }^{2}$ (SNP), which has led the government over the last decade, arranged two public consultations in 2013 and 2015, and established an expert Electronic Monitoring Working Group to discuss, consult and make recommendations to Scottish Ministers about future EM policy and practice.

In early October 2016, the Electronic Monitoring Working Group Report was released and its recommendations were endorsed immediately by the Scottish Government, committing itself to "change and expand how EM will be used in Scotland" (Graham and McIvor 2017: 68). Consequently, the Scottish Government established a new Electronic Monitoring Unit, responsible for overseeing EM practice and policy development, including the implementation of some of those recommendations. The most recent phase of this ongoing policy process revolves around the Management of

\footnotetext{
1 Scotland's prison population rate is 150 per 100,000 (02.09.2019)—one of the highest in Western Europe (https://www.prisonstudies.org/highest-to-lowest/prison_population_rate?field_region_taxonomy_tid=14).

2 The SNP is a Scottish nationalist social democratic political party, supporting campaigns for Scottish independence within the European Union. It has been leading the Scottish Government continuously since 2007.
} 
Offenders (Scotland) Bill, which was passing through the Scottish Parliament at the time of writing (December 2018). This bill expands the use of EM within the Scottish criminal justice system and highlights the need to take advantage of emerging technological developments in the field (e.g., GPS tracking).

This changing landscape poses questions about how policymakers are conceiving of EM, as well as about the nature and scope of the political conditions of their increasing practical reliance on and symbolic investment in this instrument. To date, however, research on EM has focused mainly on its effectiveness/efficiency and, more recently, professionals' understandings and monitored people's experiences of this measure.

Early Scottish research on EM was evaluative. The pioneering work by Smith (2001) on the first Scottish EM pilot scheme, by Barry and colleagues (2007) on the piloting of EM as a condition of bail, and by Deuchar (2011) on youth offenders subjected to EM, generated converging outcomes. EM was found ineffective, unlikely to make financial savings, perceived by professionals as an ambiguous instrument and with a detrimental impact on offenders' families. More recently, McIvor and Graham (2016) observed diverse attitudes toward the aims of EM among practitioners, while interviews with people undergoing EM suggested the stigmatizing effects of this instrument. Hucklesby and colleagues (2016: 4), looking comparatively at the development of EM in Europe, argued that Scotland was slowly shifting the focus "from a punishment model based on restriction of liberty to a mixed model focused on supporting rehabilitation and desistance as well as risk management."

A noteworthy exception to this empirical/evaluative body of research is that of Nellis (2006). Here, the author reconstructed the history of EM in Scotland, addressing the dynamic interplay between local politics, media and policy, thereby connecting policy with cultural and political factors. This work was part of Nellis' larger research project on the development of EM in the UK (Nellis 2000, 2005, 2014a, b, 2016) and European Union (EU) (Nellis and Bungerfeldt 2013), which exposed the neoliberal roots of this instrument. The main point here was the "'elective affinity' between the highly individuated focus of EM, and its emergence as an 'industry,' and processes of 'neoliberalization' in Europe [represented by] free (or quasi-) markets as policy instruments, the denigration (and contracting-out) of public services and reduction of public expenditure" (Nellis 2014a: 505). Similarly, Paterson $(2008,2015)$ argued that EM embodies the neoliberal ethos because it combines market competition, privatized institutions and sub-contracted, at-a-distance forms of social control within a framework of increasing emphasis on reducing the costs of crime control. Such useful engagements with EM policy and politics consist mainly of micro-analyses of the transactions between local political actors and policy networks. The political conditions of EM policy are often subsumed under the "neoliberal" heading in ways that fail, at least in part, to capture continuity and change, constitutive tensions and unexpected alliances in politics (Dunn 2017; Rose 2017).

At the opposite side of the spectrum, comprehensive studies by Feeley and Simon (1992) and Garland (2001) offered a highly theoretical (and cursory) conceptualization of EM as an example of neoliberal penality. Feeley and Simon (1992: 465) described EM as an innovative but ambiguous technique of the "new penology" which "despite the lingering language of rehabilitation and reintegration... can best be understood in terms of managing costs and controlling dangerous populations rather than social or personal transformation." Garland (2001: 4, 131) included EM within the fluid range of "highly volatile" policy developments of late modernity, which work as "non-adaptive" responses to the new "predicament of crime control." These studies offer important insights into the historical emergence of EM and its role within the changing landscape of Western penality. Yet, they 
do not engage with specific policy frameworks on this subject, also erasing the nuances of the context-specific political factors driving the regulation of EM.

A critical account of EM policy, targeting its political dimension, could help us to appreciate more fully the functions of this instrument, complementing (and to some extent challenging) the existing research on it. From this perspective, this article generates a theoretically informed policy analysis of EM in Scotland today. It then considers EM as a distinctive political technology - that is, as an instrument to govern segments of population. Overall, it puts forth an original case study on the paradoxical melange of political rationalities driving penal policymaking, whose significance may stretch well beyond British borders.

\section{Methodology}

According to Bacchi (2009, 2012; Bacchi and Bonham 2014; Bacchi and Goodwin 2016), instead of treating public policy as a government's best efforts to address a problem "out there," scholars should question how policy creates "problems," as well as "subjects," "objects" and "places." Bacchi's approach, as Bletsas and Beasley (2012: 2) explain, provides "an open-ended mode of critical practice, enabling rigorous and trenchant appraisal of policy agendas - especially those that seem axiomatic or patently obvious." It does so by reconstructing the assumptions which underlie policy representations, addressing what is taken for granted or who may be silenced in policy creation, as well as the possible effects of these processes. In addition, Bacchi's perspective encourages an examination of how those policy constructions are produced, disseminated and defended.

The first step in applying Bacchi's perspective is to generate a policy corpus. This article considers bills and supporting documents, evaluative and working group reports, guidance documents, impact statements, memoranda, news releases, public consultations and speech transcripts by the Scottish Government, Scottish Parliament and the Justice Committee published between 2013 and 2018. ${ }^{3}$ We selected this period because, as outlined above, it reflects the time during which Scotland began to produce much of its EM policy. Subsequently, we analyzed each document to ensure its relevance to our research objectives. We then applied Scott's (1990) assessment criteria of documentary sources (i.e., authenticity, credibility, representativeness, meaningfulness) to refine the dataset. After completing this stage, the final corpus consisted of seventeen $(n=17)$ documents, which we coded manually into four meta-themes_- "problems," "subjects," "objects" and "places"-focusing on: how EM policy conceptualizes certain issues as matters unwelcome or harmful and needing to be dealt with and overcome; how EM policy foregrounds the ideal actors of such "problems," excluding other possible stakeholders; how EM policy construes certain phenomena as basic units constituting those problems; and on how the EM policy fabricates the "places" where objects, problems and subjects interact (Bacchi and Goodwin 2016).

From here, we analyzed those policy constructions using the Foucauldian notion of governmentality (Foucault 2007, 2008), seeking to tease out the context-specific political logics which inform such constructions. This approach helped us to expose the multiple and

\footnotetext{
${ }^{3}$ Policy documents were retrieved from the Scottish Government (https://www.gov.scot/Publications/Recent) and the Scottish Parliament (https://digitalpublications.parliament.scot/) online databases. We used the search terms "Electronic Monitoring," "Electronic Monitoring Policy," and "Electronic Monitoring Scotland."
} 
nuanced political underpinnings of EM policy (Lippert 1998; O'Malley 1999; Pratt 2005), correcting monolithic accounts of neoliberalism as the sole compelling force behind Western contemporary penal policymaking (Dunn 2017; Rose 2017).

Accordingly, this article considers how Scottish policymakers' understandings of EM respond to a range of fluid political logics (Miller and Rose 1990; O'Malley 1999; Rose and Miller 1992; Rose et al. 2006). These are heuristic instruments helpful in organizing the multiple, overlapping, conflicting or converging rationales driving policymakers in context. We reconstructed such logics by piecing together ethical pretexts, scientific explanations, taken-for-granted worldviews (Foucault 1978: 94) used by policymakers to rationalize social issues (e.g., crime, high prison population) and to justify responses to them (e.g., supervision), shaping the normative infrastructure of EM policy in (this) context. Thus, EM policy is configured as a political technology - a set of mundane tactics which aim to organize a polity by "shap[ing], normaliz[ing] and instrumentaliz[ing] the conduct, thought, decisions and aspirations" (Miller and Rose 1990: 8) of people who offend and their "victims," as well as the aspirations, conduct, decisions and thoughts of the broader population, indirectly.

Before proceeding, we wish to offer two caveats. First, we recognize that applying a Foucauldian framework (i.e., governmentality) to an analysis of policy may appear to be incongruous, given Foucault's recommendation to "cut off the king's head" (1980: 121)— to look at how power operates at the margins of formal institutions. Nevertheless, sovereignty and its manifestations (e.g., penal policy) can still be subjected to a Foucauldian analysis (Pratt 2005: 10; cf. Hallsworth and Lea 2012). Foucault's analytic of power, as articulated, in part, through his notion of governmentality, actually affords a useful "guide for constructing better understandings of legal discourse, how it relates to power, and how its development over time reflects and shapes cultural change" (Novkov 2010: 349). ${ }^{4}$

Second, we acknowledge that policy documents are often written by different actors, for different audiences and with different goals. Because the article's primary research aim is to discern overarching policy depictions of EM and their political logics, generalization in dealing with policy documents is necessary (cf. Garland 2001: viii). In addition, a gap exists between how policies are implemented and their declared goals. This article does not address the gap between "policy in the books" and "policy in action" because it is not research on "how EM works" but an investigation of how policy construes, promotes and brings EM into being as a political instrument. Empirical explorations are needed to bridge that gap, but that is not the focus or intent of this article.

\section{Electronic Monitoring Policy}

\section{Problems}

EM policy assumes as its primary "problem" the risk of reoffending in the context of a high prison population, supposedly resulting from previous governments' policy

\footnotetext{
4 Integrating this approach with empirical methods (e.g., Lippert and Stenson 2010; McKee 2009; Stenson 2005) would certainly add a significant layer to our project. Excluding such a focus does not affect the validity of our research, either, however. Research is constitutively partial, and this article endeavors only to introduce a critical and political way of thinking about EM, opening up a new space for analysis, critique and contestation within and against EM.
} 
failures. A further problem to be "fixed" is public confidence, namely the public perception of safety when offenders are released back into the community.

In government speeches, as well as official reports on EM, "reducing reoffending" appears consistently as a justification for the development of the sanction. As the Electronic Monitoring Working Group states, EM aims to "prevent and reduce further reoffending... against the background of a persistently high remand population" (The Scottish Government 2016a: 5, 13), allowing prisoners who are "low risk to public safety and meet statutory criteria to serve the last portion of their sentence in the community" (The Scottish Government 2016a: 42). Similarly, then-Cabinet Secretary for Justice, Michael Matheson, maintained that EM "is about effective changes that stop people reoffending, make best use of emerging technology and tackle our high rate of imprisonment" (The Scottish Government 2017a). In the same year, Secretary Matheson suggested that reoffending rates are linked to previous government failures: "[since 1999], this Parliament has done great things [but] one area in which we have made little progress is that of penal reform" (The Scottish Government 2017b). This aspect is emphasized further in more recent documents regarding the Management of Offenders (Scotland) Bill, noted above. The 2018 Equality Impact Assessment, for instance, asserts that policymakers should "[c]onsider how electronic monitoring could be better used within the Criminal Justice system in Scotland" (The Scottish Government 2018b: 3). Reoffending as a "problem" to be "fixed" is linked to previous governments' ineffective/inefficient policies. Namely, inefficiency relates to the lack of an "integrated" and "goal-oriented approach" to reducing reoffending (The Scottish Government 2016a), as well as to issues in "service delivery" (The Scottish Government 2016b). EM policy recommends addressing the first sub-problem (lack of integration) by transforming EM into a multipurpose tool, geared toward "restriction" (by punishment), "reintegration" (in the community), "rehabilitation" (by promoting desistance) and "reparation" (paying back to the community the moral debt) (The Scottish Government 2013b: 3). The second issue (service delivery) can be tackled by the managerialization of EM, e.g., by streamlining criteria of non-compliance and by capitalizing on technologies like GPS tracking (The Scottish Government 2013b, 2015, 2016a, 2017a, 2018a). These strategic responses to policy failures of the past arguably express a general economically-oriented mentality, whereby the privatization of this "service" is simply taken for granted.

Public sentiment regarding safety when offenders are released is an additional "problem" that EM policy seeks to address. In 2013, then-Cabinet Secretary for Justice, Kenny MacAskill, stated, "I want to see if there is more we can do to help to further improve monitoring of offenders and give greater reassurance to the public" (The Scottish Government 2013a). The Electronic Monitoring Working Group has underscored this orientation by declaring: "Given perennial public anxiety about all forms of prisoner release, the use of Electronic Monitoring in this context could be an important means of increasing public confidence" (The Scottish Government 2016a: 5). This point is emphasized in the 2017 Consultation on Proposals for Legislation on EM, whereby the Scottish Government accepts that in the EM policy "protection of victims of crime and public safety is prioritised" (The Scottish Government 2017c). Analogously, the Equality Impact Assessment Report maintains that "[t]he Scottish Government is committed to strengthening the delivery of community justice, ensuring we continue to focus on public safety and breaking the cycle of reoffending" (The Scottish Government 2018b: 1).

Overall, EM policy presents itself as an attempt to address two main and interlinked problems: the risk of reoffending (described as inherited from previous governments) and the limited public confidence when offenders are released back into the community 
(assumed as a crucial issue for community penalties or early release). These problems concern a limited range of subjects, portrayed by EM policy in distinctive ways.

\section{Subjects}

Policy documents produce subjects by selecting, combining and positing the identities, needs and wants of those to be regulated (Bacchi and Goodwin 2016). In Scottish EM policy, the main subjects are the "offender" (to be released back into the community) and her/his "victim" (to be reassured and protected). The offender is portrayed not only as a subject "at risk of reoffending" (The Scottish Government 2013b: 3) but also in need of "support" and "structure" (The Scottish Government 2016b: 3), as well someone who needs to be "responsibilized" (The Scottish Government 2018c: 1). The Privacy Impact Assessment annexed to the Management of Offenders (Scotland) Bill, in fact, states that "those with a history of offending can be supported to be active and responsible contributors to their communities" (The Scottish Government 2018c: 1). This echoes Secretary Matheson's words on EM's capacity to "support those who end up in our justice system to turn their behaviors around and become contributors to an inclusive and respectful society" (The Scottish Government 2017c). The lack of "structure" in the offender's life is well encapsulated in the "Community justice penal reforms: minister's speech," where Secretary Matheson stated that EM "can provide stability to those whose offending is part and parcel of a chaotic lifestyle" (The Scottish Government 2017b).

Scottish EM policy addresses offenders as "chaotic" subjects in need of a social scaffold to discourage their offending. For example, the 2017 Consultation on Proposals for Legislation stresses that EM can "[s]afely and effectively manage and support those who have committed offenses to help them re-integrate into the community and realize their potential for the benefit of all" (The Scottish Government 2017c: 5). Similarly, the Electronic Monitoring Interim Guidance expresses that "[e]lectronic monitoring can be both punitive by restricting the movements of the monitored person and rehabilitative by allowing an element of structure and support to be introduced into the lives of the monitored person" (The Scottish Government 2016b: 3). It is worth noting, however, that the offender's moral deficiencies do not exempt her/him from moral responsibility. The offender has a moral debt toward the community and EM facilitates "paying back... in the community" (The Scottish Government 2013b: 3).

As for "crime victims," policy documents describe them as a homogenous group of vulnerable subjects in need of "reassurance" (The Scottish Parliament 2018d: 1). The Policy Memorandum, attached to the Management of Offenders (Scotland) Bill, states that "[t]he use of exclusion or inclusion zones that will offer victims significant reassurance and respite" (The Scottish Parliament 2018d: 1). Analogously, the Electronic Monitoring Working Group affirms that a fundamental aim of EM is " $[\mathrm{t}] \mathrm{o}$ enhance the protection and security of victims of crime in ways that other community interventions are unable to do" and that EM's legitimacy depends on the victim's perceptions: "[v]ictims of crime do need to feel that measures taken to control and rehabilitate individuals have legitimacy in their eyes" (The Scottish Government 2016a: 14). From the Electronic Monitoring Working Group's

\footnotetext{
5 We are aware of the problematic nature and potentially stigmatizing tone of both "offender" and "victim." We have elected to use them, however, in order to reflect how policy addresses the persons who have committed a crime and those have been subjected to it.
} 
perspective (The Scottish Government 2016a: 23), the modulation of the degree of monitoring - "higher intensity with higher-risk individuals" and "low intensity... for low-risk individuals" - should be fundamentally based on consideration regarding "victim safety and public protection." In the same vein, Secretary Matheson maintained that "[i]t's our duty to ensure victims see that people who are convicted of an offense are held to account, and they can be assured by the opportunities that electronic monitoring can offer" (The Scottish Government 2018a). Indeed, in the 2017 Community Justice Reform speech, Secretary Matheson emphasized the victim's centrality, remarking that the new policy provisions (including EM) "place the safety of victims at the heart of this legislation" (The Scottish Government 2017b).

Suggesting that monitored offenders always have a victim is a discursive fabrication with crucial political implications (see "Progressive" Nationalism section, below). It assumes that these offenders invariably harm a specific and identifiable individual who deserves protection. This obliterates the possibility of victimless offenders and powerful victims, as well as instances where one might be both an offender and a victim.

\section{Objects}

Offenders' "compliance" and "desistance" are two fundamental objects in EM policy. EM is primarily an instrument "to monitor an individual's compliance with a curfew" (The Scottish Government 2018b: 1). Yet, "compliance" does not refer only to the offender following the order(s) dictated by the relevant authority. Compliance entails the regulation of the offender's entire life in a way that is more subtle than requiring conformity to legal rules; it is more than mere "obedience" (The Scottish Government 2016a: 15). Compliance is about "demonstrat[ing] human development and progress over time in terms of [offenders'] rehabilitation and improvements" (The Scottish Government 2016a: 50). In addition, it is linked to a system of positive and negative rewards. Positive rewards consist of "incentives to... reduce frustration and increase commitment to completing an order" (The Scottish Government 2016a). Negative rewards are associated with breaching the order, leading to the measure being revoked (The Scottish Government 2013b: 10). In line with the non-legalistic framework outlined above, however, "[s]ome instances of non-compliance should be seen as an opportunity for the individual to understand their responsibilities and to learn something that could help them to progress" (The Scottish Government 2017c: 9). On the whole, this appears to be a form of "substantive compliance"- that is, a submission to rules expressed by "active engagement and co-operation of the offender with the requirements of his or her order," achieved when the offender "works hard and diligently" or "shows a genuine desire to tackle his or her problems" (Robinson and McNeill 2008: 434).

Compliance is integrated with "desistance" (The Scottish Government 2013b: 9, 2016a: 4) — with the offender's process of changing behavior over time to avoid further criminal involvement, mainly by increasing prosocial capital (Farrall and Calverley 2006; Maruna 2001; Weaver and McNeill 2014). EM's rehabilitative potential was emphasized in policy by the Scotland's Choice Report (The Scottish Prisons Commission 2008: 55), which assigned to EM the goal "to re-integrate an offender back into the community and to continue the rehabilitation process after a period in custody." More recently, rehabilitation is paralleled (or even replaced) by desistance. In the Electronic Monitoring Working Group Report, desistance becomes one of EM's crucial aims: "the more strategic use of EM envisaged by the Working Group [has as main aspect] to help prevent and reduce further offending and promote desistance" (The Scottish Government 2016a: 4). 
The Electronic Monitoring Interim Guidance establishes that EM should look "to help with longer-term desistance" (The Scottish Government 2016b: 11). Similarly, as Secretary Matheson asserted, "[EM] needs to be seen as a part of a package of measures and used alongside those other measures to address people's offending behavior and promote desistance" (The Scottish Parliament 2018b: 13). Within policy, desistance from crime is often linked to responsible behavior and contribution to national wealth. Along these lines, the Electronic Monitoring Working Group Report underscores that EM can help offenders to "realize their aspirations and be supported to be active, responsible contributors to our communities as fellow citizens" (The Scottish Government 2016a: 18). Likewise, the Equality Impact Assessment explains that " $\mathrm{t}]$ hose with a history of offending can be supported to be active and responsible contributors to their community" (The Scottish Government 2018b: 1). In the same vein, the Policy Memorandum, appended to the Management of Offenders (Scotland) Bill, announces that "these progressive reforms will help unlock untapped potential in Scotland's people, helping them move on more quickly from their offending behavior to assist the economy, improve their life chances, and help reduce reoffending rates" (The Scottish Parliament 2018d: 2). The Financial Memorandum similarly claims that "[t]he policy intention is that for those individuals who are on the margins of acceptable risk, electronic monitoring may provide an additional option to test an individual's readiness while maintaining public safety" (The Scottish Parliament 2018a: 5).

Desistance and compliance connect EM policy problems and subjects insofar as they are the conditions that offenders have to fulfill in order to be re-integrated in the community without threatening actual and potential victims. This process takes place in an "imagined community"-Scotland-represented by policy emphatically.

\section{Places}

"Places" are policy constructions in that they are assemblages of locales fabricated by policy as the natural stage of regulation (Bacchi and Goodwin 2016: 102). The main place in EM policy is "Scotland"-represented as a progressive and cohesive nation. The 2017 EM consultation paper asserts that the broader vision for justice in Scotland revolves around the idea of encouraging "a safer, more inclusive" nation (The Scottish Government 2017d: 5). Elsewhere, Scotland is described as a "progressive" nation (The Scottish Government 2016a: 18, 2017c: 5). Building such a nation-one that is inclusive and progressiverequires multiple instruments, including penal measures. Secretary Matheson stressed this goal in his annual speech on the future plans for the justice system in 2017: "A just, equitable and inclusive society is one that needs to be supported by a progressive, evidencebased justice system" (The Scottish Government 2017b). That EM policy could contribute to such a system is apparent in recent documents relating to the Management of Offenders (Scotland) Bill. For example, the Explanatory Notes declare that "[t]he Bill [adopts] a preventative approach to not only reduce crime and the number of future victims of crime, but to help create a more just, equitable, and inclusive society where people's life chances are improved" (The Scottish Parliament 2018c: 1). Similarly, the Privacy Impact Assessment affirms that "electronic monitoring has a role to play in supporting our vision for a safer, fairer and more inclusive nation" (The Scottish Government 2018c: 1). Such an emphasis on the Scottish nation is significant when one considers the main aim of the SNP Government - the creation of an independent nation-state. SNP political narratives often center on national identity as a way of forwarding an independent nation (Scott and Mooney 2016). Policy suggests that EM could contribute toward increasing the cohesiveness of the 
nation by punishing offenders in their community rather than in prison. This resonates with themes of civic nationalism, inclusivity, cohesion and individual rights - all of which are well established in the SNP political narrative (Stewart-Leith and Soule 2011).

\section{From Policy to Politics: Political Logics}

Policy problems, subjects, objects and places are informed by context-specific political logics. These logics are a crucial component of the broad political landscape within which EM policy emerges. By charting them, it is possible to open up new spaces for a critical political engagement with this penal instrument.

\section{"Social" Neoliberalism}

Neoliberalism is a political ideology that promotes a marked-based model of behavior in any and all aspects of social and individual life. Through a set of flexible and tentative practices, the market, i.e., the idealized smooth space of contractual relations, becomes the "site of veridiction" of behaviors, identities, policies and practices (Foucault 2008: 32). This mentality drives, inter alia, ideas about the causes of crime and the responsibility of the individual offender, the economization of EM, and the rise of victims-as-consumers of justice (Garland 2001). This neoliberal component is visible particularly in the policy representations of EM problems. The "problem" of reoffending rates is inextricably intertwined with the critique of "previous governments" enacting ineffective/inefficient policies. In light of this, recent EM policy seeks to create a cost-effective justice practice, focusing on achieving targets and increasing performance. Equally, the emphasis on "risk" of reoffending is related to the neoliberal aim of governing by individualizing social issues and generating a risk-based security (Feeley and Simon 1992). In addition, the plasticity of the "tagged" offender's life-as emerging from the discussion on compliance-is shaped around the malleable nature of the neoliberal subject, endlessly adaptable to changing environmental conditions (Chandler and Reid 2016). This neoliberal mentality is combined with a mode of government which aims to optimize the life of populations, taking "pastoral" care of (some) humans' bio-social needs (Foucault 2007: 169). This rationality informs the conceptualization of offenders as individuals in need of "structure" and "support" (cf. Nellis 2006), while driving EM's rehabilitative aim. More significantly, the concept of desistance exposes this political logic. EM policy, in fact, encourages offender's desistance in order to facilitate cooperative participation in producing socioeconomic wealth. Desistance, a concept linked to (penal) welfarism, is associated in policy to economic production, expressing the social neoliberalism espoused by the SNP (Mooney et al. 2008; Scott and Mooney 2016). This rationality presents market-oriented economic growth as a method of lessening social inequalities (Mooney and Scott 2011; Mooney et al. 2015): if the market succeeds, people will succeed, and crime will decrease.

\section{"Progressive" Nationalism}

The "social" neoliberal rationality, analyzed above, is in a mobile alliance (O'Malley 1999: 185) with a mode of government shaped around the project of re-building the nation. Work discipline, cultivation of identity and respect for local cultural traditions are the key points here. As Mooney and Williams (2006: 626) point out, national identity is a "force" 
playing an important role in influencing policy creation in Scotland. Here, nation-building is related closely to social and penal policy. This means that policy is imbued with emotive narratives which aim to create a sense of belonging, togetherness, and distinctiveness, and more generally emphasizing (rhetorically) the polity's shared qualities (Law and Mooney 2012). The language used in EM policy, in fact, suggests that SNP policymakers are trying to create a distinctive nation (Béland and Lecours 2008). "Scotland" is represented as a progressive, safe and socially cohesive place that is actively pursuing its independence (also) through a specific penal policy. As such, Scottish EM is justified on different grounds than its Anglo-Welsh counterpart—not just as a resource-saving punitive measure, but as a desistance-oriented victim-sensitive intervention-an expression of a less punitive approach to crime. This resonates with the traditional representation of Scottish penal culture as promoting behavioral change and reintegration into community (McAra 2005, 2008) within a climate of "greater collectivism of civic culture" (Croall 2006: 590; cf. MacLennan 2016). This apparently exceptional approach (compared to the "punitive" orientation of England and Wales) is presented as a reflection of the broader political uniqueness of the Scottish nation. Law and Mooney (2012) argue that SNP policy portrays Scotland as a "sentient being, whereby 'Scotland' does and feels things" (2012: 162). From this perspective, EM is not just a device to reduce reoffending, but an emotive discursive strategy embedded in a technology, which can shape behavior and ultimately contribute to the wider project of creating an independent nation. This nation-building rationality valorizes crime victims as representatives of "the people" (Rose 2017: 310). This is the point where seemingly progressive (social democratic) Scottish nationalism meets and somehow overlaps with populist (right-wing) nationalism. Victims, in fact, "do not consist simply of all those who happen to inhabit a territory, but only those who form part of that moral community of the people, who share a history, who have common values, who stand for an identity" (Rose 2017: 312). "Taking care" of crime victims by ensuring their safety equates with valorizing "the people"- the idealized law-abiding citizens whose protection against offenders is a critical item on the political agenda (Garland 2001: 11). Clearly, creating this category or class of "victim" is an othering device-a rhetorical trope which effectively includes by exclusion a dangerous other and justifies political strategies that polarize differences and restrict freedoms of those who do not belong to the nation. EM policy offers a symbolic form of reassurance not only (and not mainly) to those actually victimized by "low-risk offenders" but also (or perhaps especially) to the nation of potential victims, offering an alternative to "merely" releasing offenders back into the community and seeking to generate political consent by protecting "the people."

\section{Techno-communitarianism}

Techno-communitarianism intertwines with previous rationalities contributing to the composite political platform upon which EM policy is built. This political logic calls for the use of new technologies - techno-fixes-in order to address typical communitarian concerns, such as citizen moralization and a waning of community control. It "promise[s] to make community instantly available, now as a service (or a commodity) that can be piped into the electronic home-community, or interactivity, for domestic consumption" (Robins and Webster 2003: 226). Although this resonates with neoliberal themes (e.g., Rose 1999, 2001), to subsume this rationality under the neoliberal heading is inadequate analytically because this would erase the uniqueness of the techno-communitarian "emotional" morality that is at odds with the neoliberal self-interested ethics. EM aims to moralize-at-home 
(by promoting desistance), while enabling control-at-a-distance (by monitoring compliance) within a community characterized by a contradictory movement of embodiment/ embeddedness (the tag at home) and disembodiment/disembeddedness (criminal justice control-at-a-distance that reduces people to data, particularly through GPS). EM allows for re-socializing in such an ideal community while limiting genuine contact with "one's immediate community-whose existence frequently challenges and confounds our own" (Robins and Webster 2003: 227). This communitarian logic espouses the extension of state and state-fed private actors' competences and capacities (van Houdt and Schinkel 2013: 498). EM, in fact, is a clear example of the criminal justice net projected onto individuals by private-public partnerships, rendering its reach possibly wider and thinner (more people end up under state control and for a longer time). In addition, in this way, techno-communitarian fixes blur the private/public domain, which is also strategic to the creation of a nation, that is, to the generation of a virtual place wherein civic duties and private mores merge in a higher moral order. EM works as a hybrid device that reorganizes social reality by creating a "new" social-spatial realm (a "national community" beyond the public/private divide) whereby crime control can be exerted. Such control works primarily as a strategy of coercive responsibilization that does not assume a "pre-existing autonomous citizen, a citizen already properly socialized" (van Houdt and Schinkel 2013: 499). In fact, the monitored person is considered as lacking self-control and, consequently, requires learning responsibility by routinization and monitoring. This is a technologically enabled form of responsibilization—-de-centralized, normatively charged and hybrid.

\section{Electronic Monitoring Policy and Politics: From Critique to Disentanglement}

In the previous sections, we sought to expose critically (see Foucault 1997: 47) how EM policy generates a plan of distinctive "problems," "subjects," "objects" and "places." We then reconstructed the political logics of such policy constructions. It is our contention that this politically charged policy machine seeks to govern "offenders" and "victims" by predetermining their needs and wants, reshaping their problems, and imposing how and where to deal with them.

From this viewpoint, EM policy de-socializes offending, focussing merely on the "criminal" and her/his biography (Pathak 2014: 97), while using technology to blur the line between private and public domains. The neoliberal practice of rendering penal policy economically "efficient" is justified in the name of the offender "support" and "structure," and produces a form of freedom rooted in a techno-enabled national community. The combination between obligation to comply, freedom to desist, and morally cohesive communities, in fact, results in the production of a "centripetal" freedom (Rose 2017), whereby the offender's choices are tolerable as long as they are consistent with local/national morality (e.g., contributing to the wealth of the nation, increasing social capital, being "community-integrated"). The proliferation of themes, such as offender's responsibilization, victims' reassurance, and community payback, seems informed by the redefinition of people's relationships with themselves, through self-monitoring, reduced privacy, and routinization, transforming victims (including and perhaps mainly potential victims) and offenders' sentiments, beliefs and values in crucial political targets. EM policy, therefore, is not (only) a neoliberal penal strategy (Nellis 2014a; Paterson 2008, 2015) but a nuanced political technology whose multiple rationales are expressions of the web of political rationalities 
characterizing Scotland today, partly concealed by the institutional stability guaranteed by the SNP over the last decade.

Ostensibly, such a political melange is replete with tensions. The very idea of a "social" neoliberal logic is a contradictio in terminis because neoliberalism is ultimately about ending the social (Rose 1996). Communitarian motives and nation-building rationales clash with neoliberal ethics due to their different emphasis on conservative sociality and private self-interest. As van Houdt and Schinkel (2013: 512), note, however, "such contradictions are productive in shaping the field of crime and safety policies." From this perspective, the strength of EM policy - and possibly the reason for its appeal to policymakers more than to practitioners - is that its political platform aims to bridge "the... opposition between individual and community" (van Houdt and Schinkel 2013: 512)—between freedom and restriction-by using strategically the technological infrastructure. The final product is a paradoxical policy based on a performative yet unstable tangle of political motives.

\section{Disentanglement}

At this point, it is possible to take the political critique of EM policy further. Critique is normative in itself and does not need a theory of resistance to be valid logically or effective politically. Critique, in fact, shows the contingency of authority, thereby weakening its oppressive hold. Nevertheless, it is still possible to develop critique into political disentanglement by, in this instance, shifting the focus from denouncing EM's political logics to disputing its possible effects (cf. Maglione 2018b).

At the level of "social" neoliberal logic, the economization of EM as a response to supposedly inefficient penal policy should be contested. The ethical and political implications of this rhetorical operation-evoking efficiency failures to justify "cost-effective" policy-should be exposed, and the profit-from-pain logic denounced. The second issue is the use of desistance as a justification for normalizing the monitored person, i.e., to pressure her/him to contribute to the national wealth. The model of the offender construed by EM policy-non-productive, irresponsible, morally defective, at-risk, radically different from victims - should be opposed by focussing on criminalization, denouncing its social and political conditions, and publicizing the social harms caused to monitored people and their families/important others (cf. Kilgore 2013).

Questioning "progressive" nationalism entails highlighting the continuities between apparently progressive motives and populist themes, expressed by elevating the victim to the representative of "the people," as well as by pushing individuals to conform to the nation's moral fabric. The voices of people actually harmed and who have harmed, which often diverge from the ideal "victims" and "offenders" exploited by the populist rhetoric, should be expressed and restorative encounters promoted (Maglione 2018c).

The techno-harms caused to those who are monitored and justified by positing the prison as the only alternative to EM (rendering acceptable the humiliation of requiring permission for basic tasks and the constant fear and degradation by intrusive conditions) should be disputed by claiming that EM is already a form of incarceration. The oikos (home) as a space immune from governmental intrusions should be reclaimed.

Clearly, these proposals are ancillary to the only strategy that makes sense here: out of prison should mean out of prison. Post-release support should be provided by agencies, groups and people independent from criminal justice institutions and mentalities, market-oriented systems, nationalistic projects and hi-tech intrusive controls. And this, 
in turn, should be integral with a broader penal abolitionist approach, ${ }^{6}$ aiming to break down (analytically and materially) the prison as a contemporary institutional form of social warehousing.

To subsume this (brief) political contestation under the totalizing label of "critique of neoliberal penality" would be analytically and normatively inadequate. Only by unpacking the multiple political logics of policy, underlining their unexpected combinations, unwarranted assumptions and underlying tensions, is it possible to challenge effectively EM's governmental ambitions.

Finally, it is worth noting areas where further critical and political research on EM could be conducted. Future research should address both empirically and theoretically the subjectivizing effects of EM in context, as a dynamic integral with the political rationalities underpinning this instrument. Furthermore, spaces of situated contestation likely occur when policies are crystallized in practices and institutions (i.e., at the level of the "real governmental practice" (Foucault 2008: 2)), due to professional rivalries, lack of technical conditions, and communication short-circuits, for example. Future studies on EM should address these micro-spaces as well.

\section{Conclusions}

This article has attempted to map how EM is represented in recent Scottish penal policy and to make sense of it by reconstructing its political dimension. The research has teased out the problems, subjects, objects and places of EM policy, highlighting their underlying assumptions and charting their political logics by using a governmentality-oriented approach. Here, EM policy appears as a "technical instrument" driven by a fluid set of political-economic calculations and tactics, and aiming to govern certain segments of the population (particularly the nation of potential victims) (Foucault 2007: 144).

One of the main findings generated by this work is the context-specific web of political logics-which cannot be subsumed under the sweeping neoliberal heading-driving penal policymaking in Scotland. It is not only the emergence of EM policy, but also its inner structure, that reflects the same heterogeneity characterizing the political milieu within which it arises. EM imports into the penal policy arena a "catchall" vocabulary that includes individual responsibility in and through cohesive communities, empowering through techno-control, critique of custodial punishment and endorsement of penality, priority of (ideal) victims' needs and offenders' support. Our original, theoretically informed reflection on the politics of EM policy suggests forms of critical disentanglement while generating further questions around this instrument's subjectivizing effects, localized forms of contestation, and political destiny. Theoretical and empirical investigations of these themes are a desirable challenge ahead for a critical scholarship-beyond wellknown concerns with the effectiveness/efficiency of this penal instrument.

Acknowledgements The authors wish to thank Kirsty Boutle, Jamie Buchan and Nathan McBain for their encouragement and comments on an early draft of this paper as well as the three anonymous reviewers for their precious suggestions.

\footnotetext{
${ }^{6}$ For an overview of recent trends in penal abolitionism, see the special issue on "Penal Abolition Praxis" of Critical Criminology: An International Journal, September 2018, Volume 26, Issue 3, Pages 319-450.
} 
Open Access This article is distributed under the terms of the Creative Commons Attribution 4.0 International License (http://creativecommons.org/licenses/by/4.0/), which permits unrestricted use, distribution, and reproduction in any medium, provided you give appropriate credit to the original author(s) and the source, provide a link to the Creative Commons license, and indicate if changes were made.

\section{References}

Bacchi, C. (2009). Analysing policy: What's the problem represented to be?. Frenchs Forest: Pearson Australia.

Bacchi, C. (2012). Introducing the 'What's the Problem Represented to be?' approach. In A. Bletsas \& C. Beasley (Eds.), Engaging with Carol Bacchi: Strategic interventions \& exchanges (pp. 21-24). Adelaide: The University of Adelaide Press.

Bacchi, C., \& Bonham, J. (2014). Reclaiming discursive practices as an analytic focus: Political implications. Foucault Studies, 17, 173-192.

Bacchi, C., \& Goodwin, S. (2016). Poststructural policy analysis: A guide to practice. New York: Palgrave Macmillan.

Barry, M., et al. (2007). An evaluation of the use of electronic monitoring as a condition of bail in Scotland. Edinburgh: The Scottish Executive.

Bartels, L., \& Martinovic, M. (2017). Electronic monitoring: The experience in Australia. European Journal of Probation, 9(1), 80-102.

Béland, D., \& Lecours, A. (2008). Nationalism and social policy: The politics of territorial solidarity. Oxford: Oxford University Press.

Bletsas, A., \& Beasley, C. (2012). Introduction. In A. Bletsas \& C. Beasley (Eds.), Engaging with Carol Bacchi: Strategic interventions \& exchanges (pp. 1-9). Adelaide: University of Adelaide Press.

Chandler, D., \& Reid, J. (2016). The neoliberal subject: Resilience, adaptation and vulnerability. Lanham, MD: Rowman \& Littlefield.

Croall, H. (2006). Criminal justice in post-devolutionary Scotland. Critical Social Policy, 26(3), 587-607.

Deuchar, R. (2011). The impact of curfews and electronic monitoring on the social strains, support and capital experienced by youth gang members and offenders in the west of Scotland. Criminology \& Criminal Justice, 12(2), 113-128.

Dunn, B. (2017). Against neoliberalism as a concept. Capital \& Class, 41(3), 435-454.

Farrall, S., \& Calverley, A. (2006). Understanding desistance from crime: Emerging theoretical directions in resettlement and rehabilitation. Maidenhead: Open University Press.

Feeley, S., \& Simon, J. (1992). The new penology: Notes on the emerging strategy of corrections and its implications. Criminology, 30(4), 449-474.

Foucault, M. (1978). The history of sexuality volume I: An introduction. New York: Pantheon Books.

Foucault, M. (1980). Truth and power. In C. Gordon (Ed.), Power/knowledge. Selected interviews and other writings 1972-1977 (pp. 109-134). New York: Pantheon Books.

Foucault, M. (1982). The subject and power. In H. Dreyfus \& P. Rabinow (Eds.), Michel Foucault: Beyond structuralism and hermeneutics (pp. 208-226). Chicago: University of Chicago Press.

Foucault, M. (1997). What is critique? In S. Lotringer (Ed.), The politics of truth (pp. 41-82). Los Angeles: Semiotext(e).

Foucault, M. (2007). Security, territory, population. Lectures at the Collège de France 1977-1978. Basingstoke, Hampshire: Palgrave Macmillan.

Foucault, M. (2008). The birth of biopolitics. Lectures at the Collège de France, 1978-1979. Basingstoke, Hampshire: Palgrave Macmillan.

Garland, D. (2001). The culture of control: Crime and social order in contemporary society. Oxford: Oxford University Press.

Graham, H., \& McIvor, G. (2015). Scottish and international review of the uses of electronic monitoring (8/2015). http://www.sccjr.ac.uk/wp-content/uploads/2015/08/Scottish-and-International-Review-ofthe-Uses-of-Electronic-Monitoring-Graham-and-McIvor-2015.pdf. Accessed June 09, 2018.

Graham, H., \& McIvor, G. (2017). Advancing electronic monitoring in Scotland: Understanding the influences of localism and professional ideologies. European Journal of Probation, 9(1), 62-79.

Hallsworth, S., \& Lea, J. (2012). Reconnecting the King with his head: The fall and resurrection of the state in criminological theory. Crime Media Culture, 8(2), 185-195.

Hucklesby, A., Beyens, K., Boone, M., Dunkel, F., McIvor, G., \& Graham, H. (2016). Creativity and effectiveness in the use of electronic monitoring: a case study of five jurisdictions. https://www.crimeandju 
stice.org.uk/sites/crimeandjustice.org.uk/files/Comparative\%20Briefing_English\%2008\%2002\%20 16-3.pdf. Accessed June 09, 2018.

Jones, R. (2014). The electronic monitoring of offenders: Penal moderation or penal excess? Crime, Law and Social Change, 62(4), 475-488.

Kilgore, J. (2013). Progress or more of the same? Electronic monitoring and parole in the age of mass incarceration. Critical Criminology: An International Journal, 21, 123-139.

Law, A., \& Mooney, G. (2012). Devolution in a 'Stateless Nation': Nation-building and social policy in Scotland. Social Policy \& Administration, 46(2), 161-177.

Lippert, R. (1998). Rationalities and refugee resettlement. Economy and Society, 27(4), 380-406.

Lippert, R., \& Stenson, K. (2010). Advancing governmentality studies. Lessons from social constructionism. Theoretical Criminology, 14(4), 473-494.

MacLennan, S. (2016). Safer and stronger? The decline of the SNP's managerial competence and liberal welfarism over justice policy in government, 2007-2016. Scottish Affairs, 25(1), 62-82.

Maglione, G. (2018a). The political rationality of restorative justice. Theoretical Criminology, 23(4), $545-562$.

Maglione, G. (2018b). Pushing the theoretical boundaries of restorative justice: Non-sovereign justice in radical political and social theories. In T. Gavrielides (Ed.), Routledge international handbook of restorative justice (pp. 21-31). Abingdon, Oxon: Routledge.

Maglione, G. (2018c). The restorative justice apparatus: A critical analysis of the historical emergence of restorative justice. Social \& Legal Studies, 28(5), 650-674.

Maruna, S. (2001). Making good: How ex-convicts reform and rebuild their lives. Washington, DC: American Psychological Association Books.

Matza, D. (1969). Becoming deviant. Englewood-Cliffs, CA: Prentice-Hall.

McAra, L. (2005). Modelling penal transformation. Punishment and Society, 7(3), 277-302.

McAra, L. (2008). Crime, criminology and criminal justice in Scotland. European Journal of Criminology, 5(4), 481-504.

McIvor, G., \& Graham, H. (2016). Electronic monitoring in Scotland. The Scottish Centre for Crime and Justice Research. http://28uzqb445tcn4c24864ahmel.wpengine.netdna-cdn.com/files/2016/06/EMEUElectronic-monitoring-in-Scotland.pdf. Accessed November 09, 2018.

McKee, K. (2009). Post-Foucauldian governmentality: What does it offer critical social policy analysis? Critical Social Policy, 29(3), 465-486.

Miller, P., \& Rose, N. (1990). Governing economic life. Economy and Society, 19(1), 1-31.

Mooney, G., Croall, H., Munro, M., \& Scott, G. (2015). Scottish criminal justice: Devolution, divergence and distinctiveness. Criminology \& Criminal Justice, 15(2), 205-224.

Mooney, G., \& Scott, G. (2011). Social justice, social welfare and devolution: Nationalism and social policy making in Scotland. Poverty \& Public Policy, 3(4), 1-21.

Mooney, G., Scott, G., \& Mulvey, G. (2008). The 'Celtic Lion' and social policy: Some thoughts on the SNP and social welfare. Critical Social Policy, 28(3), 378-394.

Mooney, G., \& Williams, C. (2006). Forging new 'ways of life'? Social policy and nation building in devolved Scotland and Wales. Critical Social Policy, 26(3), 608-629.

Nellis, M. (2000). Law and order: The electronic monitoring of offenders. In D. Dolowitz (Ed.), Policy transfer and British social policy (pp. 98-117). Buckingham: Open University Press.

Nellis, M. (2005). 'Out of this world': The advent of the satellite tracking of offenders in England and Wales. Howard Journal, 44(2), 125-150.

Nellis, M. (2006). Electronically monitoring offenders in Scotland, 1998-2006. The Journal of the Scottish Association for the Study of Offending, 12, 74-98.

Nellis, M. (2014a). Understanding the electronic monitoring of offenders in Europe: Expansion, regulation and prospects. Crime, Law and Social Change, 62(4), 489-510.

Nellis, M. (2014b). Upgrading electronic monitoring, downgrading probation: Reconfiguring 'offender management' in England and Wales. European Journal of Probation, 6(2), 169-191.

Nellis, M. (2016). The strategic failure of electronic monitoring in Scotland. In H. Croall, G. Mooney, \& M. Munro (Eds.), Crime justice and society in Scotland (pp. 182-199). Abingdon, Oxon: Routledge.

Nellis, M., \& Bungerfeldt, J. (2013). Electronic monitoring and probation in Sweden and England and Wales: Comparative policy developments. Probation Journal, 60(3), 278-301.

Novkov, J. (2010). Legal archaeology. Political Research Quarterly, 64(2), 348-361.

O'Malley, P. (1999). Volatile and contradictory punishment. Theoretical Criminology, 3(2), 175-196.

Paterson, C. (2008). Commercial crime control and the electronic monitoring of offenders in England and Wales. Social Justice: A Journal of Crime, Conflict and World Order, 34(3-4), 98-110.

Paterson, C. (2015). From offender to victim-oriented monitoring: A comparative analysis of the emergence of electronic monitoring systems in Argentina and England and Wales. URBE, 7(2), 155-166. 
Pathak, P. (2014). Ethopolitics and the financial citizen. Sociological Review, 62(1), 90-116.

Payne, B., \& Gainey, R. (2000). Electronic monitoring: Philosophical, systemic, and political issues. Journal of Offender Rehabilitation, 31(3-4), 93-111.

Pratt, A. (2005). Securing borders. Detention and deportation in Canada. Vancouver: University of British Columbia Press.

Robins, K., \& Webster, F. (2003). Times of the technoculture: From the information society to the virtual life. Abingdon, Oxon: Routledge.

Robinson, G., \& McNeill, F. (2008). Exploring the dynamics of compliance with community penalties. Theoretical Criminology, 12(4), 431-449.

Rose, N. (1996). Governing 'advanced' liberal democracies. In A. Barry, T. Osborne, \& N. Rose (Eds.), Foucault and political reason (pp. 37-64). London: UCL Press.

Rose, N. (1999). Powers of freedom: Reframing political thought. Cambridge: Cambridge University Press.

Rose, N. (2001). Community, citizenship, and the third way. In M. Denise \& J. Minson (Eds.), Citizenship and cultural policy (pp. 1-17). London: SAGE.

Rose, N. (2017). Still 'like birds on the wire'? Freedom after neoliberalism. Economy and Society, 46(3-4), 303-323.

Rose, N., \& Miller, P. (1992). Political power beyond the state: Problematics of government. The British Journal of Sociology, 43(2), 173-205.

Rose, N., O’Malley, P., \& Valverde, M. (2006). Governmentality. Annual Review of Law and Social Science, 2, 83-104.

Scott, J. (1990). A matter of record: Documentary sources in social research. New York: Wiley.

Scott, G., \& Mooney, G. (2016). Scotland's political and policy landscape: Devolution, social policy and Criminal Justice. In H. Croall, G. Mooney, \& M. Munro (Eds.), Crime justice and society in Scotland (pp. 16-29). Abingdon, Oxon: Routledge.

Smith, D. (2001). Electronic monitoring of offenders: The Scottish experience. Criminal Justice, 1(2), 201-214.

Stenson, K. (2005). Sovereignty, biopolitics and the local government of crime in Britain. Theoretical Criminology, 9(3), 265-287.

Stewart-Leith, M., \& Soule, D. P. J. (2011). Whose nationalism is it anyway? In M. Stewart-Leith \& D. P. J. Soule (Eds.), Political discourse and national identity in Scotland (pp. 1-14). Edinburgh: Edinburgh University Press.

van Houdt, F., \& Schinkel, W. (2013). A genealogy of neoliberal communitarianism. Theoretical Criminology, 17(4), 493-516.

Weaver, B., \& McNeill, F. (2014). Lifelines. Criminal Justice and Behavior, 42(1), 95-107.

\section{Policy Documents}

The Scottish Government. (2013a). Satellite tracking of offenders. Retrieved from https://news.gov.scot/ news/satellite-tracking-of-offenders.

The Scottish Government. (2013b). Development of electronic monitoring in Scotland: A consultation on the future direction of the electronic monitoring service. Retrieved from http://www.gov.scot/Publi cations/2013/09/7937.

The Scottish Government. (2015). The future of electronic monitoring. Retrieved from https://news.gov.scot/ news/the-future-of-electronic-monitoring.

The Scottish Government. (2016a). Electronic monitoring in Scotland working group report. Retrieved from http://www.gov.scot/Publications/2016/10/8620/0.

The Scottish Government. (2016b). Electronic monitoring-Interim guidance. Retrieved from http://www. gov.scot/Topics/Justice/policies/reducing-reoffending/Electronic-Monitoring/Electronic-Monitoring -Interim-Guidance.

The Scottish Government. (2017a). Electronic monitoring to cut reoffending. Retrieved from https://news. gov.scot/news/electronic-monitoring-to-cut-reoffending.

The Scottish Government. (2017b). Community justice penal reforms: Minister's speech. Retrieved from https://beta.gov.scot/publications/community-justice-penal-reforms-ministers-speech/.

The Scottish Government. (2017c). Electronic monitoring in Scotland: A consultation on proposals for legislation. Retrieved from https://beta.gov.scot/publications/electronic-monitoring-scotland-consultationproposals-legislation/.

The Scottish Government. (2017d). Electronic monitoring in Scotland: analysis of consultation responses. Retrieved from https://beta.gov.scot/publications/analysis-responses-electronic-monitoring-scotlandconsultation-proposals-legislation/. 
The Scottish Government. (2018a). New ways to improve public safety proposed. Retrieved from https:// news.gov.scot/news/new-ways-to-improve-public-safety-proposed.

The Scottish Government. (2018b). Management of offenders (Scotland) bill-Equality impact assessment-Electronic monitoring. Retrieved from http://www.gov.scot/Publications/2018/02/3152.

The Scottish Government. (2018c). Management of offenders (Scotland) bill-Electronic monitoring provisions-Privacy impact assessment_Electronic monitoring. Retrieved from https://www.gov.scot/Publi cations/2018/02/1135.

The Scottish Parliament. (2018a). Management of offenders (Scotland) bill: Financial Memorandum. Retrieved from http://www.parliament.scot/Management\%20of\%20Offenders\%20(Scotland)\%20Bill/ SPBill27FMS052018.pdf.

The Scottish Parliament. (2018b). Justice committee, 17th meeting 2018, session 5. Retrieved from http:// www.parliament.scot/parliamentarybusiness/report.aspx $\mathrm{r}=11582 \&$ mode $=$ pdf.

The Scottish Parliament. (2018c). The management of offenders (Scotland) bill-Explanatory notes. Retrieved from http://www.parliament.scot/Management\%20of\%20Offenders\%20(Scotland)\%20Bill/ SPBill27ENS052018.pdf.

The Scottish Parliament. (2018d). The management of offenders (Scotland) bill: Policy memorandum. Retrieved from http://www.parliament.scot/Management $\% 20$ of $\% 20$ Offenders $\% 20$ (Scotland)\%20Bill/ SPBill27PMS052018.pdf.

The Scottish Prisons Commission. (2008). Scotland's choice: Report of the Scottish Prisons Commission, July 2008. Retrieved from Scottish Prisons Commission website: http://www.gov.scot/Resource/ Doc/230180/0062359.pdf.

Publisher's Note Springer Nature remains neutral with regard to jurisdictional claims in published maps and institutional affiliations. 